\author{
Agnieszka Niezgoda \\ Akademia Ekonomiczna w Poznaniu \\ Katedra Turystyki \\ al. Niepodległości 10 \\ 60-967 Poznań \\ tel/fax (061) 8543766 \\ a.niezgoda@ae.poznan.pl
}

\section{ROLA RÓŻNYCH KONCEPCJI I FORM ROZWOJU TURYSTYKI \\ W DAŻ̇ENIU DO CELÓW ROZWOJU ZRÓWNOWAŻONEGO}

Abstrakt: W artykule przedstawiono koncepcję rozwoju zrównoważonego $\mathrm{z}$ podkreśleniem triady współzależnych celów ekonomicznych, ekologicznych i spolecznych, które warunkują istotę tej koncepcji. Na tle tej charakterystyki przedstawiono znaczenie turystyki w dążeniu do celów rozwoju zrównoważonego $\mathrm{z}$ uwzględnieniem opisanych $\mathrm{w}$ literaturze różnych form rozwoju turystyki. Zaprezentowano pojęcia turystyki łagodnej, zielonej, agroturystyki, a przede wszystkim ujęcie turystyki alternatywnej i ekoturystyki, jako koncepcji odzwierciedlajacych cele rozwoju zrównoważonego. Szczególną uwagę poŚwięcono również zakresom pojęć turystyki alternatywnej oraz turystyki masowej w aspekcie ich zazębiania bądź wykluczania, co wynika z jakościowego i ilościowego ujęcia turystyki masowej. Podsumowaniem toku wywodu jest przedstawienie koncepcji turystyki zrównoważonej.

Słowa kluczowe: rozwój zrównoważony, turystyka alternatywna, turystyka masowa, turystyka zrównoważona.

\section{WSTĘP}

Przemiany, jakie nastapiły w Polsce po roku 1989 spowodowały wzrost zainteresowania ekonomicznymi skutkami rozwoju turystyki, które w skali świata umożliwiają traktowanie jej jako jednej z najbardziej dynamicznie rozwijających się dziedzin gospodarki. Pomimo coraz większej liczby publikacji dotyczących zarówno rozwoju turystyki, jak też ogólnie rozumianych procesów rozwoju brak jest wszechstronnej wiedzy na temat możliwości stymulowania pożądanego, zrównoważonego rozwoju przez turystykę. Częstym błędem jest traktowanie turystyki jako dziedziny wyizolowanej zamiast zin-

\section{THE ROLE OF DIFFERENT TOURISM CONCEPTS AND FORMS IN THE PURSUANCE OF SUSTAINABLE DEVELOPMENT GOALS}

\begin{abstract}
The article presents the concept of sustainable development, underlining the interrelations between ecological, economic and social goals that provide its foundation. Against this background it discusses the role of tourism in the realization of sustainable development objectives by referring to the various forms of tourism development described in the literature. The concepts of soft tourism, green tourism, agrotourism, and - in particular - alternative tourism and ecotourism, are presented as forms compatible with the goals of sustainable development. Special attention is given to alternative tourism and mass tourism in terms of their coexistence or mutual exclusion in the light of qualitative and quantitative characteristics of forms of mass tourism. The article concludes with a presentation of the concept of sustainable tourism.
\end{abstract}

$\underline{\text { Key words: }}$ sustainable development, alternative tourism, mass tourism, sustainable tourism.

\section{INTRODUCTION}

The socio-economic changes initiated in Poland after 1989 have led to a growing interest in the economic effects of tourism development, the more so that tourism is one of the most dynamic sectors of the global economy. Notwithstanding a growing number of publications on tourism development or, more broadly understood, development processes, there is a dearth of multidisciplinary knowledge on the possibilities of stimulating desired sustainable development through tourism. A frequent mistake is to view tourism as an isolated discipline rather 
tegrowanego podejścia, w którym rozwój dotyczy wszystkich aktywności występujących na danym obszarze, a turystyka (pod warunkiem właściwej diagnozy uwarunkowań jej rozwoju) może stanowić główną lub jedną z wielu funkcji gospodarczych determinujących procesy rozwojowe. Dla analizowania tych procesów szczególnego znaczenia nabiera koncepcja rozwoju zrównoważonego.

\section{ROZWÓJ ZRÓWNOWAŻONY - ISTOTA I CELE KONCEPCJI}

Koncepcja rozwoju zrównoważonego (sustainable development) pojawiła się na gruncie badań tendencji rozwojowych i formułowania ostrzeżeń przed globalnymi konsekwencjami rozwoju cywilizacji, a w szczególności wzrostu gospodarczego.

W początkowej fazie tworzenia koncepcji sustainable development $\mathrm{w}$ literaturze polskiej autorzy najczęściej określają go mianem ekorozwój. Od momentu ukazania się raportu „Nasza wspólna przyszłość", a także oficjalnego thumaczenia Deklaracji z Rio de Janeiro i Agendy 21 coraz częściej zamiast „ekorozwój” używane jest pojęcie „rozwój zrównoważony” i „trwaly rozwój” (CZAJA, FIEDOR, GRACZYK, JAKUBCZYK 2002; URBANIAK 2000; ŻABIŃSKA 2000; ŹYLICZ 2004). Wynika to ze zmian $\mathrm{w}$ definicjach prezentowanych $\mathrm{w}$ dokumentach wyjściowych (IWICKI 1998). W Raporcie Brundtland uwzględniono fakt, że kapitał przyrodniczy stanowiący podstawę zagadnień ekologicznych jest tylko jednym ze składowych zasobów niezbędnych do zaspokajania potrzeb. Pozostałe składowe to kapitał wytworzony przez człowieka (antropogeniczny, rzeczowy) oraz społeczny i ludzki. Koncepcja rozwoju zrównoważonego opiera się na umiejętnym wykorzystaniu wszystkich typów kapitału. Według wielu autorów (ŻABIŃSKA $2000 \mathrm{i}$ in.), pojęcie „ekorozwój” nie oddaje całości treści sustainable development $\mathrm{i} \mathrm{w}$ odniesieniu do języka polskiego można zastosować je w węższym, głównie ekologicznym znaczeniu. Należy zgodzić się z takim stanowiskiem, ponieważ niszczenie środowiska naturalnego jest wprawdzie czynnikiem o doniosłym znaczeniu dla przyszłości świata, ale nie wyczerpuje listy zagrożeń, przed którymi trzeba szukać zabezpieczenia w realizowaniu koncepcji sustainable development. Rozwój zrównoważony wraz z różnorodnymi efektami ekologicznymi zapewnia również korzyści ekonomiczne i społeczne. Ponadekologiczny wymiar zagadnienia uwzględniony został w najważniejszych, polskich dokumentach państwowych. than one requiring an integrated approach considering all activities in a given geographic area, where tourism - provided its development prospects are properly diagnosed - can become a leading or at least one of many economic functions determining development processes.

\section{SUSTAINABLE DEVELOPMENT: THE CONCEPT AND GOALS}

The idea of sustainable development emerged from research on the global consequences of civilization trends, particularly related to economic growth.

When the idea of sustainable development was still in its early stages of conceptualization, commentators in the literature referred to it as 'eco-development'. Since the publication of the United Nations' Brundtland Report 'Our common future' and official translations of Agenda 21 and the Rio Declaration on Environment and Development, the term 'eco-development' has increasingly been replaced with the terms 'balanced development' or 'sustainable development' (CZAJA. FIEDOR, GRACZYK \& JAKUBCZYK 2002; URBANIAK 2000, ŻABIŃSKA 2000; ŻYLICZ 2004), a change reflected in official published documents (IwICKI 1998). The Brundtland Report points out that that the global environmental equity on which ecological issues are founded is only one of several component resources needed to satisfy the needs and interests of humans. The other components are the equity created by man (anthropogenic, material), social equity and human capital. Sustainable development relies on the skilful usage of all these resources simultaneously. According to many commentators (ŻABIŃSKA et al.), the term 'eco-development' does not convey the full meaning of the 'sustainable development' concept, and in the Polish language should be used in a narrower sense, chiefly in reference to the natural environment. This approach is reasonable given that the degradation of the natural environment, however alarming for the world's future, does not exhaust the list of threats dealt with in the concept of sustainable development. Besides providing positive environmental impacts, sustainable development is equally focused on economic and social benefits. The 'supraecological' dimension of the issue has been acknowledged in the most important Polish 
W Ustawie z 27 kwietnia 2001 r. Prawo ochrony środowiska, rozwój zrównoważony określany jest jako: „taki rozwój społeczno-gospodarczy, w którym następuje proces integrowania działań politycznych, gospodarczych i społecznych, z zachowaniem równowagi przyrodniczej oraz trwałości podstawowych procesów przyrodniczych, w celu zagwarantowania możliwości zaspokajania podstawowych potrzeb poszczególnych społeczności lub ich obywateli zarówno współczesnego, jak i przyszłych pokoleń ".

Takie ujęcie rozwoju zrównoważonego uwypukla wspólzależność ładu ekologicznego, ekonomicznego, społecznego i przestrzennego w rozwoju społeczno-gospodarczym oraz konieczność zachowania zasobów dla przyszlych generacji.

Proces rozwoju zrównoważonego powinien prowadzić do wzrostu dobrobytu społeczno-ekonomicznego. Na jego poziom wpływaja, poza bezpośrednia konsumpcją dóbr i usług, zasób dóbr już nagromadzonych tworzących infrastrukturę społecznoekonomiczną, możliwości rekreacji i wypoczynku, jakość środowiska przyrodniczego, a także elementy o charakterze socjologicznym i psychologicznym. Celem rozwoju zrównoważonego staje się zatem podnoszenie jakości życia. Rozwój zrównoważony można uznać jako antropocentryczny w tym sensie, że ukierunkowany jest na poprawę warunków życia ludzkiego, a jednocześnie zawiera komponent konserwacyjny, ponieważ uwzględnia konieczność zagwarantowania odpowiednich warunków funkcjonowania przyrody.

Reasumując, rozwój zrównoważony powinien być celem polityki władz państwowych, samorządowych i jednostek gospodarczych, a jego efektem powinno być podnoszenie jakości życia. Zgodne z polityką państwa, zasady zrównoważonego rozwoju przekładać się muszą na różne dziedziny gospodarki. W odniesieniu do gospodarki turystycznej związane są one $\mathrm{z}$ koncepcją turystyki nie tylko efektywnej ekonomicznie, ale przyjaznej środowisku (przyrodniczemu, społecznemu i kulturowemu).

\section{ROZWÓJ ZRÓWNOWAŻONY A FORMY ROZWOJU TURYSTYKI}

Efekty społeczno-ekonomiczne rozwoju turystyki postrzegać można przez pryzmat korzystnych zmian w postaci: wzrostu dochodów z turystyki, wzrostu zatrudnienia, poprawy standardu życia społeczności odwiedzanych, poprawy i rozwoju infrastruktury, rozwoju przedsiębiorczości itd. Należy być jednak świadomym występujących także niekorzystnych state documents and legislation. In the Law on the Protection of the Environment of $27^{\text {th }}$ April 2001, sustainable development is defined as a socio-economic development in which in order to guarantee the satisfaction of the basic needs of societies or their citizens - both present and future generations - a process of integrated political, economic and social effort is put in motion to ensure the preservation of natural balances and the durability of fundamental biological processes'.

This rendition of the sustainable development concept underlines the interdependence of ecological, economic, social and spatial orders in socio-economic development, and emphasizes the need to preserve resources for future generations.

Sustainable development must lead to an improvement in socio-economic welfare. Besides direct consumption of goods and services, socio-economic welfare depends on the accumulated pool of resources forming the socio-economic infrastructure as well as on opportunities for outdoor rest and recreation, the quality of the natural environment, and also on sociological and psychological factors. Hence the ultimate goal of sustainable development is to improve the quality of life. In this sense sustainable development, focused on improvement in the human living conditions, is anthropocentric. However, it also contains an element of environmental protection by declaring a commitment to the proper functioning of natural environment.

In summary, sustainable development should be adopted as a policy objective by national governments, local authorities and the business community, and it should lead to an improvement in the quality of life.

\section{SUSTAINABLE DEVELOPMENT AND FORMS OF TOURISM DEVELOPMENT}

The socio-economic effects of tourism development can be perceived in the context of positive changes such as growing revenues from tourism, increased employment, better living standards in the host communities, infrastructural improvement and development, and the emergence of local entrepreneurship. 
zjawisk towarzyszących rozwojowi turystyki i miejsc, w których rozwój ten następuje.

Dysfunkcje turystyki dotyczą w szczególności zjawisk o charakterze społecznym i przestrzennym, a przejawiają się wzrostem patologii społecznych, niszczeniem krajobrazu i degradacją walorów środowiska przyrodniczego i kulturowego. Te zjawiska wpływają na jakość walorów turystycznych, co w długim okresie może przynieść negatywne skutki w aspekcie konkurencyjności miejsca przyjmującego turystów. Przejawiać się to może nie tylko w zmniejszeniu atrakcyjności turystycznej, ale obniżeniu odczuwanej przez mieszkańców satysfakcji z jakości życia, co wywołać może odpływ kapitału społecznego do obszarów bardziej atrakcyjnych. Powoduje to osłabienie potencjału społecznego i ekonomicznego danego terytorium, co potwierdza, że niekontrolowany rozwój turystyki może mieć negatywne implikacje również w sferze ekonomicznej.

W wyniku krytyki zjawiska pojawia się określenie ,turystyka masowa", o pejoratywnym wydźwięku. Można jednak zauważyć, że poza negatywnymi skutkami (uciążliwość dla otoczenia oraz dla samych turystów) turystyka masowa może mieć swoje uzasadnienie ekonomiczne (kosztowe), a także związane z postrzeganiem atrakcyjności danego miejsca (NIEZGODA 2006).

Uzasadnienie ekonomiczne związane jest z koniecznością odpowiednio wysokiego wykorzystania infrastruktury w celu pokrycia kosztów, przy czym należy pamiętać o wysokiej kapitałochłonności, jaka charakteryzuje znaczną część infrastruktury turystycznej (np. hotelarstwo, transport). Atrakcyjność miejsca wynikająca $\mathrm{z}$ masowego charakteru ruchu turystycznego dotyczy głównie imprez sportowych, kulturalnych, festiwali, kongresów, zjazdów itp. Negatywny wydźwięk turystyki masowej związany jest w znacznej mierze ze szkodami wyrządzanymi w środowisku, w którym następuje rozwój turystyki.

Tak jak w opisanym procesie adaptacji i wprowadzania w życie koncepcji rozwoju zrównoważonego, tak w odniesieniu do turystyki autorzy skupiają się często na kwestiach stricte ekologicznych. W literaturze przedmiotu występuje wiele pojęć związanych z turystyką przeciwstawną wobec turystyki uznawanej za szkodliwą ekologicznie. Jednak upowszechnianie wiedzy na temat rozwoju zrównoważonego znajduje odzwierciedlenie $\mathrm{w}$ debacie dotyczącej procesów rozwojowych związanych z zachowaniem środowiska społecznego i kulturowego. Rozszerzenie rozważań o aspekt społeczny i ekonomiczny daje wgląd $w$ problematykę różnych koncepcji rozwoju turystyki. Powstają one przede
One must, however, also acknowledge the negative impacts of tourism development. Dysfunctions can be observed particularly in social and spatial phenomena, such as increased social pathologies and the degradation of scenery and the natural environment, or the degradation of cultural heritage. In the long run such phenomena have a negative impact on the quality of tourist experience, undermining the competitiveness of affected destinations. This is reflected not only in the lower tourism attractiveness of a destination but also in the frustration of local residents dissatisfied with the declining quality of life which can result in the migration of social capital to more attractive areas. The weakening of social and economic potential of such affected areas confirms the thesis that uncontrolled development of tourism has negative implications also for the economy.

The negatively charged term 'mass tourism' is used to emphasize the bad aspects of this particular phenomenon. However, despite its obviously negative impacts (on the environment, local communities, and even on tourists), mass tourism can be justified on the grounds of economy (costs) and can even contribute to the perception of a destination as an attractive place (NIEZGODA 2006).

The economic justification of mass tourism is based on the fact that tourism investments (hotels, transportation) are capitalintensive, so in order to provide an adequate return on assets and cover the running costs of facilities the infrastructure requires a high degree of utilisation (occupancy). The attractiveness of a mass tourism destination is often connected with sport and cultural events, festivals, congresses, conventions, etc. The negative connotation of mass tourism usually refers to the damage inflicted on the environment in which tourism development takes place.

Referring to tourism in the context of sustainable development, commentators often focus on strictly ecological issues. The subject literature uses numerous terms to describe types of tourism that are environmentally benign as opposed to harmful forms. The understanding of the sustainable development concept is, however, spreading, as reflected in the popular debate on the preservation of social and cultural environments. The extension of the debate to include social and economic issues gives an insight into the various concepts of tourism development. These concepts are based 
wszystkim w oparciu o analizę trendów rozwojowych popytu, ale dotyczą również podaży turystycznej. Przedstawiony poniżej przegląd dotyczy tych koncepcji rozwoju i form rozwoju turystyki, które związane są z celami rozwoju zrównoważonego.

Turystyka lagodna (soft tourism) jest koncepcją wprowadzoną w Szwajcarii w połowie lat 70., za prekursora której uznaje się J. Krippendorfa (JĘDRZEJCZYK 1995; SCHMITT 1999). Turystykę lagodną określa się jako przeciwieństwo twardej (hard tourism), czyli powodującej szkody ekologiczne. Twórcy tej koncepcji podkreślaja, że jest ona wynikiem zmian potrzeb turystów, a najważniejszym jej celem jest ukazanie i zrozumienie istoty zjawisk w turystyce oraz możliwości jej rozwoju, a nie stworzenie zamkniętej teorii. Istota tej koncepcji wynika z wymagań do: oferty turystycznej bliskiej naturze uwzględniającej walory niepowtarzalnego i niezmienionego przez działalność ludzką krajobrazu, zgodności rozwoju turystyki z możliwościami rozwoju społeczno-kulturowego, wkomponowania rozwoju turystyki w strategie regionalne. W literaturze spotkać można inne pojęcia związane $\mathrm{z}$ nowymi koncepcjami rozwoju turystyki, które powstały na gruncie turystyki łagodnej.

Turystyka zielona (green tourism) akcentuje ochronę przyrody. W literaturze niemiecko- i anglojęzycznej spotyka się również określenia naturnäher oraz nature-based używane dla rozwoju turystyki przebiegającego $\mathrm{w}$ oparciu o zasoby naturalne (SCHMITT 1999; Weaver 2001; HopkINS, PrICE 2002). Mankamentem takiego rozwoju turystyki jest częste ograniczanie postrzegania walorów do pojedynczych atrakcji naturalnych występujących na danym obszarze. Turyści, na przykład, chcą zobaczyć żubry w Białowieży, bociany na Podlasiu czy Mazurach, a nie uwzględniaja w motywacjach swoich podróży szeroko rozumianego środowiska przyrodniczego i społeczno-kulturowego. Rozwój podaży turystycznej w oparciu o pojedyncze walory, bez uwzględnienia holistycznych zjawisk (przyrodniczych, kulturowych) na danym obszarze, nie zawsze będzie prowadzić do rozwoju tego obszaru w sensie zrównoważonym. Należy uważać na unikatowość pojedynczych atrakcji w kreowaniu produktu turystycznego, ponieważ jednostronne wyeksponowanie takiego waloru może wplynać negatywnie na całość ekosystemu. Rezultatem troski i odpowiedzialności za skutki rozwoju turystyki, zwłaszcza społeczne i kulturowe jest koncepcja turystyki odpowiedzialnej (responsible; angepast) oraz turystyki przyjaznej środowisku (environmental friendly), w której nacisk położony jest nie tylko na środowisko przy- mainly on an analysis of demand trends, but can also refer to the supply side in tourism. The following part of the article presents a review of tourism development concepts and forms compatible with the goals of sustainable development.

Soft tourism. This concept emerged in the 1970s in Switzerland, with Krippendorf recognised as its precursor (JEDRZEJCZYK 1995, SchmitT 1999). Soft tourism is placed in opposition to ecologically harmful hard tourism. The concept's authors highlight the fact that it resulted as a response to changes in the tourist's needs, and the primary objective of the idea is to show and understand the nature of tourism phenomena rather than create a closed theory. The concept is based on the following assumptions: the tourism offer must be nature-based and take account of its needs in terms of the preservation of its uniqueness and beauty unspoilt by human activity; tourism development must be compatible with socio-cultural development goals and limitations; tourism development must be integrated into regional strategies.

The concept of soft tourism has provided the base for other forms of tourism development cited in the subject literature.

Green tourism. This concept focuses on the protection of nature. In the German and English literature commentators use the terms naturnäher or nature-based respectively to describe tourism development based on its resources (SCHMITT 1999; Weaver 2001; Hopkins \& Price 2002). A deficiency of tourist activity based on this concept lies in the frequent limitation of offers to a single natural attraction. For example, tourists want to see the European bison in Białowieża or storks in Podlasie and Mazury, disregarding in their travel motivation the broader aspects of natural and socio-cultural environments. Tourism supply based on single attractions without regard to holistic phenomena of the visited region (natural and cultural) will not always lead to sustainable development of the destination. Special care must be taken in the development of a destination's tourism product since the exposition of a single attraction can have a negative impact on the ecosystem integrity.

Concern and responsibility for the effects of tourism development, especially its social and cultural impacts, have led to the concepts of responsible tourism and environmentally friendly tourism, in which the emphasis is 
rodnicze, lecz także społeczne i kulturowe, obejmujące wszystkie obszary i sektory turystyki (zarówno obszary ,zielone”, czyli np. chronione i wiejskie, jak i duże miejscowości turystyczne) (MAJEWSKI, LANE 2001; ZARĘBA 2000). Podkreślenie znaczenia środowiska nie zawsze uwzględnia aspekt społeczno-kulturowy, co nie przekreśla podstawowego znaczenia środowiska przyrodniczego. Środowisko odgrywa dwojaką rolę w rozwoju turystyki. Po pierwsze, zapewnia walory, atrakcyjność i niepowtarzalność produktu turystycznego, po drugie, odbiera negatywne skutki rozwoju turystyki (zanieczyszczenie, zatłoczenie). Pamiętać zatem należy, że środowisko stanowi podstawę tworzenia produktu turystycznego, ale jest również otoczeniem dla gospodarki turystycznej przejmując niekorzystne skutki wynikające z jej rozwoju.

W odpowiedzi na potrzeby rozwoju turystyki zgodnej ze środowiskiem pojawiają się formy turystyki związane z rolnictwem. Należą tu agroturystyka (agrotourism), w której gospodarstwo rolne stanowi bazę noclegową oraz główną atrakcję dla turysty, oraz szerzej rozumiana turystyka wiejska (rural tourism, country tourism), której podstawą jest przyjazd na tereny wiejskie. Innymi formami turystyki wynikającymi z potrzeb popytu coraz bardziej wyedukowanego i wymagającego społeczeństwa są formy oparte na konkretnych typach walorów turystycznych: turystyka kulturowa, turystyka przygodowa $i$ in. Rozwój popytu turystycznego oraz zgodny z rynkowym nastawieniem odpowiadający pojawiającym się potrzebom rozwój podaży prowadzi do coraz to nowych możliwości $i$ form uprawiania turystyki. Nie jest możliwe wymienianie wszystkich takich form, powstaja pewne połączenia i różnorodne interpretacje. D. WEAVER (2001) nazywa je hybrydami, a proces ich powstawania ilustrować może przykładowa koncepcja tzw. turystyki ACE, która jest amalgamatem turystyki przygodowej (adventure), kulturowej (cultural) i ekoturystyki (ecotourism).

Znaną i rozpowszechnioną koncepcją jest koncepcja turystyki alternatywnej (alternative) rozumiana jako przeciwieństwo i alternatywa turystyki masowej. Koncepcja ta powstała na gruncie buntu przeciwko cywilizacji przemysłowej i konsumpcyjnemu modelowi życia, który powoduje niszczenie środowiska i autentycznych relacji między ludźmi. Koncepcja związana jest ze zjawiskami lat 60., kiedy narodziła się w USA kontrkultura hippisowska. Turystyka alternatywna miała być nowym stylem podróżowania, miała stanowić przeciwwagę do rozwijającej się ekspansywnej, skomercjalizowanej tu- placed not only on the natural environment but also on the social and cultural environments in all types of tourism destinations (including protected and rural areas as well as large tourism destinations) (MAJEWSKI \& LANE 2001; ZAREBA 2000). The environment, both natural and socio-cultural even though the latter is not always implied in the usage of the term - has two aspects in the tourism development debate. On the one hand the environment is a source of attractions on which the uniqueness of a tourism product is based, and on the other it bears the brunt of the negative impacts of tourist activity (pollution, overcrowding). It must be remembered, therefore, that the environment - providing the basis for tourism products and tourism economy alike - is exposed to the negative effects of tourism development.

A demand for environmentally-friendly tourism has resulted in the emergence of agriculture-based tourism such as agrotourism, where a farm provides both the source of attractions and accommodation for the tourist, and a broader concept of rural tourism (country tourism). Other forms of tourism devised to meet the needs of better educated and increasingly sophisticated societies are based on specific types of attractions and include such types as culture tourism and adventure tourism. A growing tourism demand and the corresponding growth in tourism supply aimed at meeting the new needs of the market results in the development of more-and-more new forms of tourist activity. It would be difficult to list all the possible forms, the more so that a number of types can be combined in packages which WEAVER (2001) calls 'hybrids'. An example of such is $\boldsymbol{A C E}$ tourism combining adventure, culture and ecotourism.

A well-known and popular concept is alternative tourism seen as the opposite and a substitute for mass tourism. This concept, built on the rebellion against industrial civilization and consumerism blamed for the degradation of the environment and destruction of authentic relations between people, is related to the 1960s hippie counterculture in the United States. Alternative tourism was intended to become a new style of travelling as a counterbalance to the fastgrowing, expansive, commercialised mass tourism destroying the natural environment through intensive developments. Many young tourists do not want to be identified with the 'tourist behaviour of city-dwellers engaging in incessant pursuit of ease, 
rystyki masowej niszczącej przez intensywne zagospodarowanie środowisko naturalne. Wielu młodych turystów nie chce utożsamiać się z ,zachowaniami turystycznymi mieszczaństwa pozostającego w nieustannej pogoni za komfortem, wygoda, blichtrem" (JĘDRZEJCZYK 1995). Nowi turyści chcą omijać zatłoczone centra turystyczne, poszukują kontaktu z miejscowa ludnościa, przeciwstawiają się izolacji turystów w specjalnych enklawach. Często motywy ich podróżowania związane są z krajoznawstwem i edukacja.

Wspólczesne pojęcie „turystyka alternatywna” wprowadza pewien zamęt do terminologii przedmiotu. Niektórzy uważaja, że jest to każda forma turystyki „małej skali” w przeciwieństwie do turystyki masowej. A więc wszystko co alternatywne ma być dobre, a to co masowe, złe i negatywne (KousIS 2000; ZARĘBA 2000). A przecież turystyka masowa może wpływać również pozytywnie na rozwój pewnych obszarów. Takie nieporozumienia wynikaja $\mathrm{z}$ faktu, iż turystyka masowa (mass tourism) rozumiana jest w sensie zarówno ilościowym, jak i jakościowym. W kontekście ilościowym turystyka ma charakter masowy, ponieważ uprawiana jest w szerokich, zróżnicowanych kręgach spolecznych. Nie oznacza to, że $\mathrm{z}$ definicji nie jest ona zgodna $\mathrm{z}$ rozwojem zrównoważonym (NIEZGoDA 2004). Dobrze zaplanowana, wprowadzona zgodnie $\mathrm{z}$ chłonnościa obszaru recepcji turystycznej, turystyka uprawiana przez wielu turystów, może być przyjazna środowisku (część AM na rys. 1).

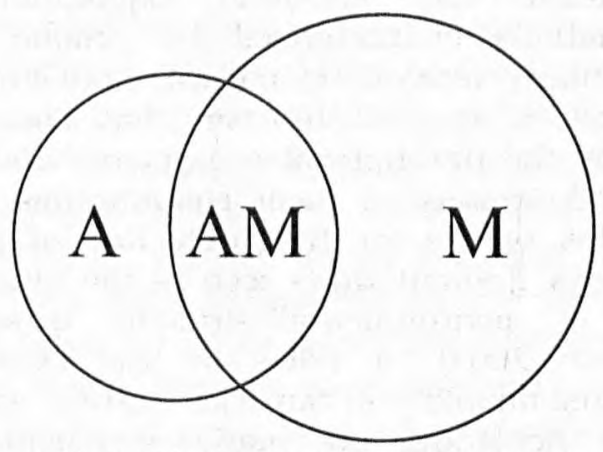

A - turystyka alternatywna, M - turystyka masowa

Rys. 1. Zakresy pojęć „turystyka alternatywna” i „turystyka masowa” (ż ró d ło: opracowanie własne)

Negatywny wydźwięk terminu ,turystyka masowa" ma charakter jakościowy i związany jest ze stylem podróżowania związanym $\mathrm{z}$ konsumpcyjnym stylem życia i podróżowania, ,zaliczaniem atrakcji”, eksploatowaniem środowiska, brakiem kontaktu comfort, and tinsel' (JEDRZEJCZYK 1995). The new tourists are determined to avoid crowded tourist destinations. Insisting on personal contact with local communities, they reject the isolation of tourists in closed enclaves. Often their motivation for moving around comes from the need for 'travel-learning' experience.

Contemporary interpretations of alternative tourism cause certain confusion in the subject terminology. Some people believe that this is any form of 'small scale' tourism as opposed to mass tourism. So anything 'alternative' is good, whereas 'mass' is bad and destructive (KousIS 2000; ZAREBA 2000). But like any tourist activity, mass tourism can also have a positive impact on the development of certain areas. The misconceptions arise from the fact that mass tourism is analysed both in quantitative and qualitative aspects. In its quantitative side this form of tourism is mass because it is pursued by a wide variety of social and economic groups. It does not mean that by definition mass tourism is not compatible with sustainable development (NIEZGODA 2000). Well planned and implemented in accordance with the carrying capacity of a destination, mass tourism can be environmentally friendly (see part AM in fig. 1.1).

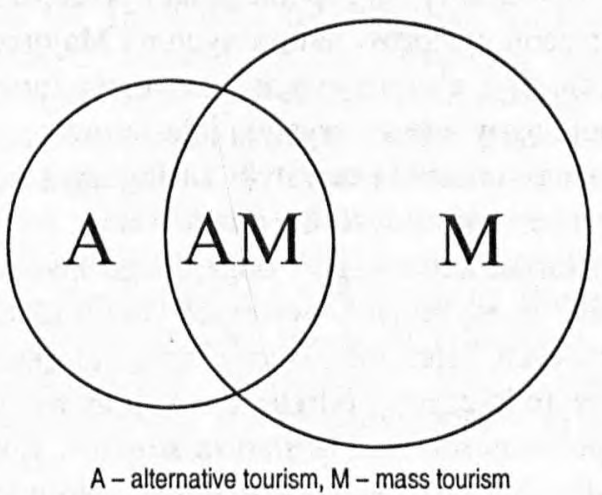

Fig. 1. The scopes of alternative and mass tourism concepts (s o u r c e: A. Niezgoda)

The negative undertone of 'mass tourism' is qualitative and refers to the consumptive style of travelling, 'ticking off attractions, exploitation of the environment, no interaction with local communities, and only superficial contact with the culture of visited destinations (part $\mathrm{M}$ in fig. 1). 
z miejscową ludnością oraz powierzchownym poznawaniem kultury terenów odwiedzanych (część M na rys. 1).

Można zauważyć, że turystyka „małej skali” nie jest alternatywą turystyki masowej. Dotyczy ona bowiem sposobu podróżowania, którego cechy wynikają zarówno z motywacji turystów, jak też formy organizowania wyjazdów. Taka turystyka nie jest $\mathrm{z}$ definicji przyjazna środowisku. Tak jak turystyka masowa, musi być wprowadzana zgodnie z zasadami rozwoju zrównoważonego obszaru recepcji turystycznej i poddawana procesowi ekologizacji. Można zgodzić się z D. WEAVEREM, który twierdzi, że „turystyka masowa stanowi pewne kontinuum turystyki alternatywnej, że nie są to dwie odseparowane kategorie, a granica pomiędzy nimi jest niejasna i przejściowa". Powyższe problemy sygnalizowane są w literaturze również $\mathrm{w}$ odniesieniu do innych koncepcji turystyki. T. SCHMITT (1999) zauważa, że zmniejszanie liczby turystów i traktowanie turystyki jako „niszy rozwoju” dla wspomnianej koncepcji turystyki łagodnej prowadzi do ograniczenia rozwoju obszarów recepcyjnych, a turyści są odizolowani, co prowadzi do jeszcze poważniejszych różnic pomiędzy ludnością miejscową a przybyszami. Według tego autora, cele turystyki łagodnej mogą być aplikowane do turystyki rozwijającej się w dużej skali (masowej). Można zgodzić się z tym stanowiskiem uwzględniając wspomniany podział na ujęcie ilościowe i jakościowe turystyki masowej. T. Schmitt, przedstawiając rozwiązania dla zapobiegania i przeciwdziałania niszczeniu walorów naturalnych na Majorce wywołanych zbyt ekstensywnym rozwojem turystyki, proponuje rozwój tzw. turystyki jakościowej.

Kolejną koncepcją turystyki zasługująca na wyjaśnienie jest ekoturystyka (ecotourism), rozumiana jako forma aktywnego i dogłębnego zwiedzania obszarów o wybitnych walorach przyrodniczych i kulturowych, która nie niszczy harmonii ekosystemów przyrodniczych i odrębności kulturowej lokalnych społeczności, oraz dostarcza środków finansowych dla ochrony tych elementów. Ekoturystyka uznawana jest za „najczystszą” formę podróżowania przyjaznego środowisku (WEAVER 2001). Warunkiem jej rozwoju jest występowanie obszarów o najwyższych walorach przyrodniczych. Zgodnie z uwagami wielu autorów (WEAVER 2001; ZARĘBA 2000), ekoturystyka wpływa na procesy uczenia zachowań społeczeństwa zgodne z zasadami zachowania zasobów naturalnych i kulturowych oraz przynosi realne korzyści ludności miejscowej dostarczając środków na ochronę zasobów.
It is apparent that 'small scale' tourism is not the alternative of mass tourism. The term refers to the mode of travelling whose features result both from the tourists' motivation and the way travelling is organized. Such tourism is not 'by definition' environmentally friendly. Just like mass tourism it must comply with the principles of sustainable development of a tourist destination and undergo a process of 'ecologization'. One must agree with Weaver who claims that there is a continuum between mass tourism and alternative tourism, and that these two forms are not entirely separate as the boundaries between them are too blurred and transitory.

In the literature commentators point to similar problems encountered with other tourism concepts. SCHMITT (1999) observes that limiting the number of tourists and treating tourism as a 'development niche', as in the case of soft tourism, constrains development of destinations, and leads to the insulation of tourists from local communities, exacerbating differences between residents and visitors. According to this author, the objectives of soft tourism can also be applied in large scale (mass) tourism. Given the quantitative-qualitative dichotomy of mass tourism this standpoint is acceptable. As one of the solutions aimed at preventing environmental damage on Majorca caused be intensive tourism development, Schmitt proposes a so-called 'quality tourism'.

Another tourism concept deserving explanation is ecotourism, understood as an active and profound exploration of destinations characterised by unique and particularly interesting natural and cultural features, a type of tourism that does not destroy the harmony of ecosystems and the cultural identity of local communities, and provides money for the protection of these elements. Ecotourism is seen as the 'cleanest' form of environmentally-friendly travelling (WEAVER 2001). It relies on the existence and sustainability of superior natural attractions. According to many commentators (WEAVER 2001; ZAREBBA 2000) ecotourism contributes to the education of societies to behave in line with the principles of the preservation of natural and cultural resources and brings tangible benefits to local communities by providing finances for the protection of resources.

Many authors point out that the concept of ecotourism is often confused with other forms (such as soft, nature-based, green, alternative or even active tourism) (HoPkINS 
Wielu autorów zauważa, że koncepcja ekoturystyki mylona jest często $\mathrm{z}$ innymi formami (lagodna przyrodnicza, zielona, alternatywną a nawet kwalifikowana) (HOPKINS, PRICE 2002; JĘDRZEJCZYK 1995; ZARĘBA 2000). Utrudnia to opracowywanie planów, strategii oraz wprowadzanie konkretnych rozwiązań taktycznych związanych z procesami rozwoju obszarów recepcji turystycznej.

W dyskusji dotyczącej ekoturystyki pojawiają się zdania krytyczne wobec tej formy turystyki. K.W. HOPKINS I G.G. PRICE (2002) podkreślają, że organizatorzy turystyki skupiają się na doraźnych korzyściach ekonomicznych używania pojęcia „ekoturystyka" w celu sprzedaży regionów lub produktów bez zwracania uwagi na zasady leżące u podstaw ekoturystyki. Jeszcze bardziej surową krytykę ekoturystyki przedstawia K. MEETHAN (2001). Autor ten prezentuje dyskusyjne opinie, że ekoturystyka jest $z$,natury fałszywa i nieuczciwa, jako że - by wyrazić to w prostych słowach - biznes i natura nie idą z sobą w parze". Jest to pogląd krańcowy, ale trzeba pamiętać, że wprowadza on do dyskusji nową myśl, a mianowicie, nie wszystko co nowe nadaje się jako podstawa teoretyczna do kształtowania strategii rozwojowych.

Należy wybrać koncepcję rozwoju (w tym turystyki) zgodną z możliwościami danego obszaru. Takie poglądy akcentują istnienie luki w wiarygodności opracowywanych koncepcji i teorii związanych Z rozwojem turystyki. $Z$ drugiej strony należy się wystrzegać dodatkowych definicji i rozczłonkowywania koncepcji na coraz bardziej szczegółowe, ponieważ mogą one wprowadzić dodatkowy chaos, którego wynikiem może być brak zrozumienia podstawowych założeń teorii, która powinna mieć charakter aplikatywny w stosunku do praktyki. Przykladem takich koncepcji jest podział ekoturystyki na: "ekoturystykę samodzielną”, „ekoturystykę w małych grupach” i „ekoturystykę popularną” (HoPKINS, PRICE 2002). Podział taki jest zbyt szczegółowy, a opiera się on na charakterze odwiedzanych miejsc, stopniu kontaktu ze środowiskiem naturalnym, liczebności grupy turystycznej, stopniu korzystania z przewodników, rodzaju transportu, potrzebach w zakresie usług dodatkowych, a także spodziewanego przeżycia i zadowolenia z podróży. Biorąc pod uwagę argumenty ekonomiczne, ale też o charakterze bardziej ogólnym (filozoficznym) określające różne podejścia do zagadnienia rozwoju zrównoważonego, można znaleźć podział na ekoturystykę „dogłębną" i „powierzchowną” (HoPKINS, PRICE 2002). W literaturze anglojęzycznej wprowadzone zostają też pojęcia turystyki „ekstrakty-
\& PRICE 2002; JEDRZEJCZYK 1995; ZARĘBA $2000)$. This is a source of additional difficulty in developing plans and strategies, and in implementing specific tactical solutions for the development of tourist destinations.

In the ecotourism debate some criticism is voiced about this form of tourist activity. HOPKINS \& PRICE (2002) suggest that tourism organizers, focused on immediate economic benefits, use the term 'ecotourism' to sell destinations and products without regard to the principles underlying the concept. An even more severe criticism is voiced by MEETHAN (2001). This author expresses a somewhat controversial opinion that ecotourism is by nature false and dishonest as - to put it simply - business and nature do not go hand-in hand'. This is an extreme standpoint but nevertheless introduces a new thought to the debate, arguing that not every new thing is good enough to be used as a theoretical base for development strategies.

Development concepts (including tourism strategies) should correspond with capabilities of a given area. Views like that expressed by Meethan expose a credibility gap in tourism development concepts and theories. However, we should warn against formulating new, even more precise definitions of tourism forms and conceptions as they are likely to introduce additional chaos, confusing the basic tenets of theories which should be applicable in practice. An example of such treatment is the breaking down of ecotourism into 'individual ecotourism', 'ecotourism in small groups', and 'popular ecotourism' (HOPKINS \& PRICE 2002). A division like that - based on criteria such as destination characteristics, degree of contact with nature, the number of tourists in the group, guide service usage, mode of transport, need for additional services, and expected satisfaction from travel experience - is far too detailed.

By economic and more general (philosophical) criteria, ecotourism can even be divided into 'profound' and 'superficial' types (HOPKINS \& PRICE 2002). The English language literature has also introduced the notions of 'extractive' (consumptive) and 'nonextractive' tourism. The implied devastating nature of extractive tourism lies in the expropriation of natural resources and processing them to be sold in the consumer goods market' (Weaver 2001; PEChlaner \& OSTI 2002). This division, however, does not appear to be significant since any form of tourism 
wnej" (extractive, consumptive) i ,nie-ekstraktywnej". Wyniszczający charakter turystyki ekstraktywnej polega na ,zawłaszczaniu zasobów naturalnych i przetwarzaniu ich w celu sprzedaży na rynku dóbr konsumpcyjnych" (WEAVER 2001; PECHLANER, OSTI 2002). Ten podział nie wydaje się znaczący $\mathrm{z}$ uwagi na fakt, że każda forma turystyki może być zaklasyfikowana jako ekstraktywna $\mathrm{z}$ uwagi na fakt niszczenia środowiska.

Można zauważyć, że debata na temat definicji związanych z różnymi koncepcjami rozwoju turystyki jest pozbawiona pewnej precyzji, a różnorodność występujących definicji powoduje pewien chaos w ich interpretacji. Wydaje się jednak oczywiste, że należy badać te koncepcje w celu zrozumienia istoty zjawiska, co umożliwia wprowadzenie w praktyce takich rozwiązań, które przyczynią się do rozwoju obszarów zgodnych z koncepcja rozwoju zrównoważonego.

Jako wynik badania powiązań pomiędzy turystyką, środowiskiem i rozwojem pojawiła się koncepcja turystyki zrównoważonej. Można spotkać wyraźne stanowisko, że jej rozwój jest logiczną konsekwencja pogłębiania wiedzy na temat procesów rozwojowych (SHARPLEY 2002). Wedlug definicji Federacji Parków Narodowych i Rezerwatów Przyrody Europy, turystyka zrównoważona to:

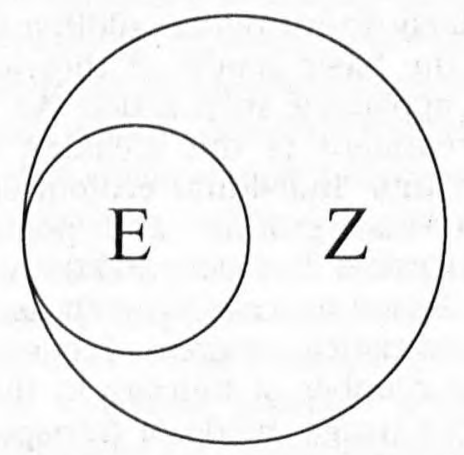

E- ekoturystyka, Z - turystyka zrównoważona

Rys. 2. Zakresy pojęć "ekoturystyka” i „turystyka zrównoważona” (z r ó d ło: opracowanie własne)

„każda forma rozwoju turystycznego, zarządzania i aktywności turystycznej, która podtrzymuje ekologiczną, społeczną i ekonomiczną integralność terenów, a także zachowuje w niezmienionym stanie zasoby naturalne i kulturowe tych obszarów" (ZARĘBA 2000). Podstawę koncepcji turystyki zrównoważonej stanowi zatem osiagnięcie harmonii między potrzebami turystów, środowiska naturalnego i lokalnych społeczności. can be classified as extractive by its negative impact on the environment.

It appears that the debate on definitions of various tourism concepts lacks precision, and a multitude of functioning definitions causes interpretive chaos. Nevertheless it is beyond doubt that all those concepts deserve to be studied and understood to enable practical implementation of development solutions compatible with the idea of sustainable development.

The concept of sustainable tourism emerged as a result of research on interrelations between tourism, the environment, and development. SHARPLEY (2002) claims that the concept is a logical consequence of development process studies. The Federation of National Parks and Protected Areas of Europe defines sustainable tourism as any form of tourism development, tourism activity and tourism management that maintains ecological, social and economic integrity of areas, and preserves in unaltered state the natural and cultural resources of these areas' (ZAREBA 2000). The basis of sustainable tourism, therefore, is a harmony between tourists' needs, the natural environment, and local communities.

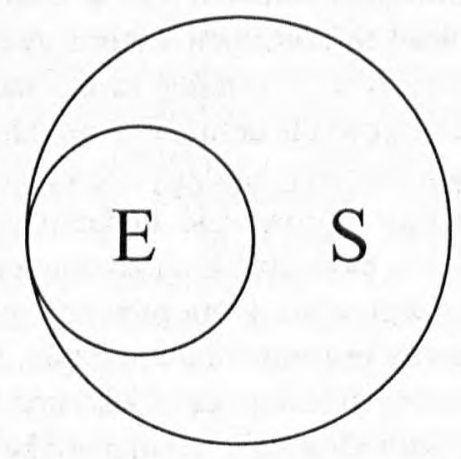

E-ecotourism, $S$ - sustainable tourism

Fig. 2. The scopes of ecotourism and sustainable tourism concepts (s o u r c e: A. Niezgoda)

In the subject literature ecotourism is sometimes seen as synonymous with sustainable tourism whereas it would be more precise to treat ecotourism as the core of sustainable tourism (ZAREBA 2000). Safeguarding the harmony of ecosystems and cultural identity of local communities, and providing finances for effective protection of cultural and natural heritage, ecotourism is a form of sustainable tourism, but not every 
W literaturze można spotkać potraktowanie ekoturystyki jako synonimu turystyki zrównoważonej. Nie jest to ujęcie precyzyjne, bowiem ekoturystyka stanowi „rdzeń” turystyki zrównoważonej (ZARĘBA 2000). Strzegąc harmonii ekosystemów, odrębności kulturowych mieszkańców i dostarczając środków finansowych na skuteczną ochronę wartości dziedzictwa kulturowego i przyrodniczego, ekoturystyka jest formą turystyki zrównoważonej, ale nie każda forma turystyki zrównoważonej jest równoznaczna z ekoturystyką (rys. 2). Wynika to z szerokiego kontekstu turystyki zrównoważonej, która nie jest zawężona tylko do celów ekologicznych, lecz obejmuje również cele ekonomiczne i społeczne obszarów przyjmujących turystów, co odpowiada koncepcji rozwoju zrównoważonego.

W literaturze przedmiotu można spotkać różne, często sprzeczne poglądy na temat turystyki zrównoważonej (ŻABIŃSKA 2000; HUNTER 1995; MÜLLER, FLÜGEL, 1999; NIEZGODA 2006). Jednak ważny staje się fakt, że turystyka zrównoważona może obejmować różne formy i rodzaje turystyki, pod warunkiem, że będą one zgodne $\mathrm{z}$ uwarunkowaniami oraz planowanym rozwojem danego obszaru. form of sustainable tourism is the same as ecotourism (Fig. 2). This is because sustainable tourism, keeping in view the economic and social goals of tourist destinations, has a much broader context than just ecology, which is consistent with the concept of sustainable development.

The subject literature features different, often contradictory views on sustainable tourism (ŻABIŃSKA 2000; HUNTER 1995; MÖlleR \& FlÜGEL 1999; NIEZGODA 2004, 2006). However, it is an important fact that sustainable tourism can embrace diverse forms and types of tourism, provided that they are consistent with the character and planned development of the destination.

\section{BIBLIOGRAFIA - BIBLIOGRAPHY}

CZAJA, S., Fledor, B., GRACZYK, A., JAKUBCZYK, Z., 2002. Podstawy ekonomii $i$ środowiska zasobów naturalnych. Wydawnictwo C.H. Beck, Warszawa.

HopkINS, K.W., PrICE, G.G., 2002, Ecotourism's Competitive Advantage? Environmental Education. [w:] Tourism and the Environment, Sustainability in Tourism development, ed. N. Andrews, F. Convery, S. Flanagan, J. Ruddy, Institute of Technology, Dublin.

HunTER, C., 1995, Sustainable Tourism as an Adaptative Paradigm, Annals of Tourism Research, vol. 24, nr 4.

Iwıckı, S., 1998 Turystyka $w$ zrównoważonym rozwoju obszarów pojeziernych, Akademia Techniczno-Rolnicza, rozprawy $\mathrm{nr} 87$, Bydgoszcz.

JEDRZEJCZYK, I., 1995, Ekologiczne uuarunkowania i funkcje turystyki. Wyd. Slask, Katowice.

Kousis, M., 2000. Tourism and The Environment. A Social Movements Perspective, Annals of Tourism Research, vol. 7 , nr 2 .

MAJEWSkI, J., LANE, B., 2001, Turystyka wiejska i rozuój lokalny. Fundacja Fundusz Współpracy, Poznań.

meethan, K., 2001. Tourism in global society. Place, Culture, Consumption. Palgrave.

MƯller, H., Flơgel, M., 1999, Tourismus und Ökologie. Forschungsinstitut für Freizeit und Tourismus der Universität Bern.

NiezGodA, A., 2004, Problems of implementing sustainable tourism in Poland, The Poznan University of Economics Review, vol. 4, nr 1/2004, Wydawnictwo Akademii Ekonomicznej w Poznaniu, Poznań.

NiEzGODA, A., 2006, Obszar recepcji turystycznej $w$ warunkach rozwoju zrównowaźonego. Wydawnictwo Akademii Ekonomicznej w Poznaniu, Poznań.
Pechlaner, H., Ostr, L., 2002, Heritage Conservation as a Challenge for Sustainable Tourism. [w:] Tourism and the Environment. Sustainability in Tourism development. ed. N. Andrews, F. Convery, S. Flanagan, J. Ruddy. Institute of Technology, Dublin.

SHARPLEY, R., 2002, Sustainability: A Barier to Tourism Development?, [w:] Tourism and Development, Aspect of Tourism 5, ed. R. Scharpley, D. Telfer, Channel View Publications, Clevendon-Buffalo-Toronto-Sydney.

ScHMrtt, T., 1999, Ökologische Landschaftsanalyse und bewertung in ausgewählten Raumeinheiten Mallorcas als Grundlage einer umweltverträglichen Tourismusentwicklung, Franz Steiner Verlag, Stuttgart.

URBANIAK, M., 2000. Sustainable development. Wprowadzenie do systemowej koncepcji ekorozwoju. Katedra Polityki Gospodarczej i Planowania Rozwoju. Akademia Ekonomiczna, Poznań.

Ustawa Prawo ochrony środowiska, art. 3. ,pkt 50., Dz. U., nr 62, poz. 627.

WEAVER, D., 2001, Ecotourism, John Wiley \& Sons, Melbourne.

ZAREBA, D, Ekoturystyka, 2000, Wyzuania i nadzieje, Wydawnictwo Naukowe PWN, Warszawa.

ŻABINSKA, T., 2000, Paradygmat turystyki zrównoważonej a rozwój turystyki na obszarach chronionych, [w:] Gospodarka turystyczna u progu XXI wieku, red. S. Bosiacki, AWF, Poznań.

ŻYLICZ, T., 2004, Ekonomia środowiska i zasobów naturalnych, PWE, Warszawa. 